\title{
LENGTH-WEIGHT RELATIONS OF SEVEN NATIVE FISH SPECIES (ACTINOPTERYGII) FROM THE LOUROS RIVER, GREECE
}

\author{
Anthi OIKONOMOU*, Chryssa ANASTASIADOU, Thomas TASKOUDIS, \\ and Ioannis D. LEONARDOS
}

Laboratory of Zoology, Department of Biological Applications and Technology, University of Ioannina, Greece

\begin{abstract}
Oikonomou A., Anastasiadou Ch., Taskoudis Th., Leonardos I.D. 2014. Length-weight relations of seven native fish species (Actinopterygii) from the Louros River, Greece. Acta Ichthyol. Piscat. 44 (2): $163-165$.

Abstract. Length-weight relations were estimated for 7 native fish species of the Louros River in north-western Greece, 6 of them being endemic to the Ionian Sea ecoregion. The $b$ values ranged from 3.05 to 3.21 . Five species, namely Cobitis hellenica Economidis et Nalbant, 1996; Pelasgus thesproticus (Stephanidis, 1939); Gasterosteus gymnurus Cuvier, 1829; Economidichthys pygmaeus (Holly, 1929); and Valencia letourneuxi (Sauvage, 1880) displayed an isometric growth pattern $(b=3)$ while the remaining two species-Salmo lourosensis Delling, 2011 and Telestes pleurobipunctatus (Stephanidis, 1939) — showed a positive allometric growth $(b>3)$. New maximum lengths are given for three species. Moreover, this study constitutes the first world report on the length-weight relations for 5 species and the first report for the Ionian Sea ecoregion for two other species.
\end{abstract}

Keywords: Length-weight relations, Louros River, native fish, Cyprinidae, Gasterosteidae, Salmonidae, Valenciidae

There is an increasing interest in scientific literature regarding fish length-weight relations (LWRs), (see Froese et al. 2011 for details). Yet, fisheries management and conservation have been increasingly relying on LWRs which when properly estimated, can be informative on the condition factor and somatic growth type (isometric or allometric) of a fish species (Le Cren 1951). LWRs can also be used for the determination of the biomass, since they allow the conversion of length to weight. They are also useful in life history studies (Petrakis and Stergiou 1995, Froese et al. 2011) and/or in comparisons of species growth between sexes, among seasons and regions (Froese 2006, Moutopoulos et al. 2013).

Up to now, the knowledge on the length-weight relations of the freshwater fishes in Greece have suffered either from a limited number of species investigated (Tsoumani et al. 2006, Tsoumani et al. 2013) or focused mainly on lake ecosystems (Kleanthidis et al. 1999, Tsoumani et al. 2006, Bobori et al. 2010), and river ecosystems (Petriki et al. 2011, Sapounidis et al. 2011).

The Louros River is located in north-western Greece (Ionian Sea ecoregion, Oikonomou et al. 2014). It is a spring-type river with a rather stable mean flow $\left(10.6 \mathrm{~m}^{3} \cdot \mathrm{s}^{-1}\right)$ throughout the year, relatively small length $(73.5 \mathrm{~km})$ and the drainage area $\left(952 \mathrm{~km}^{2}\right)$, and an annual discharge of $0.95 \mathrm{~km}^{3}$ (D’Alessandro et al. 2013). The Louros River delta is char- acterized by high ecological value at both national and international level. In the presently reported study, we estimated the LWR parameters for 7 native fish species sampled from the Louros River, namely Cobitis hellenica Economidis et Nalbant, 1996; Pelasgus thesproticus (Stephanidis, 1939); Gasterosteus gymnurus Cuvier, 1829; Economidichthys pygmaeus (Holly, 1929); and Valencia letourneuxi (Sauvage, 1880); Salmo lourosensis Delling, 2011; and Telestes pleurobipunctatus (Stephanidis, 1939).

Fish samples were collected bi-monthly from December of 2011 until November of 2012, from nine stations along the main river course. The samplings were conducted using a backpack portable electrofishing device (Hans Grassl type IG200/2) by a single downstream-to-upstream zigzag pass. All individuals were identified in situ according to Kottelat and Freyhof (2007). The fish were subsequently photographed, weighted, and released back into the river following national policy-relevant sampling protocols. Total weight (TW) was determined to the nearest $0.001 \mathrm{~g}$ using a digital portable balance and the standard length (SL) was measured to the nearest $0.1 \mathrm{~mm}$ using the ImageJ software (1.47 version).

The LWR parameters were estimated according to the formula:

$$
W=a L^{b}
$$

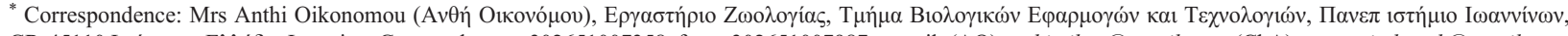

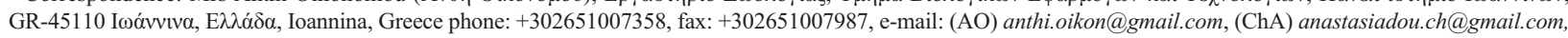

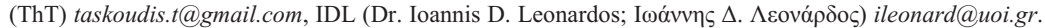


Estimated parameters of the length-weight relations of seven native fish species of the Louros River, Greece

\begin{tabular}{|c|c|c|c|c|c|c|c|c|c|c|c|c|c|c|}
\hline \multirow{2}{*}{$\mathrm{F}$} & \multirow{2}{*}{ Species } & \multirow{2}{*}{ IUCN } & \multirow{2}{*}{$n$} & \multicolumn{2}{|c|}{$\mathrm{SL}[\mathrm{cm}]$} & \multicolumn{2}{|c|}{$\mathrm{TW}[\mathrm{g}]$} & \multicolumn{5}{|c|}{ Parameters of the length-weight relations } & \multirow{2}{*}{$P$} & \multirow{2}{*}{$t$-test } \\
\hline & & & & Min & Max & Min & Max & $a$ & $95 \%$ CI of $a$ & $b$ & $95 \% \mathrm{CI}$ of $b$ & $r^{2}$ & & \\
\hline $\mathrm{Cb}$ & Cobitis hellenica $\bullet$ & EN & 15 & 2.609 & 7.131 & 0.171 & 3.545 & 0.008 & $0.005-0.013$ & 3.094 & $2.723-3.466$ & 0.961 & $<0.001$ & 0.55 \\
\hline \multirow[t]{2}{*}{$\mathrm{Cp}$} & Telestes pleurobipunctatus & $\mathrm{LC}$ & 279 & 2.017 & 12.888 & 0.121 & 42.440 & 0.012 & $0.011-0.013$ & 3.210 & $3.158-3.263$ & 0.981 & $<0.001$ & $7.86^{*}$ \\
\hline & Pelasgus thesproticus $\bullet$ & NT & 105 & 1.692 & 6.178 & 0.071 & 5.348 & 0.016 & $0.013-0.020$ & 3.107 & $2.972-3.243$ & 0.953 & $<0.001$ & 1.57 \\
\hline Gs & Gasterosteus gymnurus & $\mathrm{LC}$ & 89 & 1.501 & 5.792 & 0.060 & 2.524 & 0.014 & $0.012-0.016$ & 3.076 & $2.958-3.194$ & 0.969 & $<0.001$ & 1.28 \\
\hline $\mathrm{Gb}$ & Economidichthys pygmaeus $\bullet$ & $\mathrm{LC}$ & 219 & 1.247 & 5.142 & 0.030 & 2.946 & 0.017 & $0.015-0.019$ & 3.052 & $2.944-3.161$ & 0.934 & $<0.001$ & 0.95 \\
\hline $\mathrm{Sa}$ & Salmo lourosensis $\bullet$ & - & 42 & 6.587 & 31.899 & 4.093 & 602 & 0.015 & $0.011-0.019$ & 3.098 & $3.003-3.193$ & 0.991 & $<0.001$ & $2.07 *$ \\
\hline $\mathrm{Va}$ & Valencia letourneuxi $\bullet$ & CR & 13 & 1.593 & 4.415 & 0.048 & 1.943 & 0.017 & $0.011-0.027$ & 3.166 & $2.641-3.691$ & 0.941 & $<0.001$ & 0.69 \\
\hline
\end{tabular}

- constitutes the first world report on the LWR, Bold: new maximum standard lengths, ${ }^{*} b$ statistically different from 3 at 0.05 significance level; F = family, IUCN = IUCN Conservation Status, $n=$ number of individuals, SL $=$ standard length, $\mathrm{TW}=$ total weight, $\mathrm{CI}=$ confidence intervals, $r^{2}=$ coefficient of determination, $P=P$ value of $b ; \mathrm{Cb}=\mathrm{Cobitidae}, \mathrm{Cp}=$ Cyprinidae, $\mathrm{Gs}=$ Gasterosteidae, $\mathrm{Gb}=$ Gobiidae, $\mathrm{Sa}=$ Salmonidae, $\mathrm{Va}=$ Valenciidae; $\mathrm{CR}=$ critically endangered, $\mathrm{EN}=$ endangered, $\mathrm{LC}=$ least concern, NT = near threatened.

by the least squares method through the transformed equation (Tesch 1971):

$\log \mathrm{TW}=\log a+b \cdot \log \mathrm{SL}$

where: TW is the total weight of the fish [g], SL is the standard length [cm], $a$ is the intercept, and $b$ is the slope of the regression line. The statistical significance level of the coefficient of determination $\left(r^{2}\right)$ and $95 \%$ confidence limits of $a$ and $b$ were also estimated. Obvious outliers were identified and removed, according to the plot of the $\log$ TW over log SL (Froese 2006). The estimated $b$ values were tested by $t$-test to check whether the growth of each species is isometric ( $b=3$, all fish dimensions increase at the same rate), negative allometric $(b<3$, a fish increases less in weight than predicted by its increase in length), or positive allometric ( $b>3$, a fish increases more in weight than predicted by its increase in length) (Froese et al. 2011). All analyses were performed in the R statistical and programming environment ( $R$ 3.0.2, Anonymous 2013).

A total of 762 individuals, representing 6 families and 7 species, were measured. The family and species name, IUCN Conservation status, sample size $(n)$, SL and TW ranges, intercept $a$, slope $b, 95 \%$ confidence intervals of $a$ and $b, P$ values of $b$ and coefficient of determination $\left(r^{2}\right)$ are summarized in Table 1. Length and weight data were pooled together for each species without sampling site and sex discrimination. The sample size ranged from 13 individuals for Valencia letourneuxi and 15 for Cobitis hellenica to 219 for Economidichthys pygmaeus and 279 for Telestes pleurobipunctatus, respectively. All relations were statistically significant $(P<0.001)$, with high $r^{2}$ values ranging from 0.934 (Economidichthys pygmaeus) to 0.991 (Salmo lourosensis).

The $a$ values obtained ranged from 0.008 (Cobitis hellenica) to 0.017 (Economidichthys pygmaeus and Valencia letourneuxi). The values of $b$ rose from 3.05 for Economidichthys pygmaeus to 3.21 for Telestes pleurobipunctatus. The majority of the species displayed isometric growth $(b=3)$. Two species (Salmo lourosensis and Telestes pleurobipunctatus) exhibited a positive allo- metric growth $(b>3)$. Yet, the allometric growth of Salmo lourosensis has been already observed by Liasko et al. (2012) under the morphological analysis of the native trout populations of north-western Greece. Since described $b$ values correspond to the observed length ranges, extrapolation of these parameters to different length ranges should be handled with caution (Petrakis and Stergiou 1995).

To the best of our knowledge, herein, new maximum lengths are presented for Economidichthys pygmaeus $\left(\mathrm{SL}_{\max }=5.142 \mathrm{~cm}\right)$, Pelasgus thesproticus (Stephanidis, 1939) $\left(\mathrm{SL}_{\max }=6.178 \mathrm{~cm}\right)$, and Salmo lourosensis $\left(\mathrm{SL}_{\max }=31.899 \mathrm{~cm}\right)$ (Table 1). Moreover, this study constitutes the first world report on the LWRs for 5 species (Cobitis hellenica, Economidichthys pygmaeus, Pelasgus thesproticus, Salmo lourosensis, and Valencia letourneuxi). For two species (Gasterosteus gymnurus and Telestes pleurobipunctatus) we provided the first length-weight relation parameters for the Ionian Sea ecoregion.

\section{ACKNOWLEDGEMENTS}

We express our gratitude to the drivers of the University of Ioannina and $\mathrm{K}$. Triantis for their help during the field samplings. We are also grateful to the personnel of the Amvrakikos Wetlands National Park for providing us with the necessary permissions. We thank F. Leprieur and R. Liasko for comments and discussion during the analysis procedure. Two anonymous reviewers provided helpful and thorough comments in a previous version of the manuscript.

\section{REFERENCES}

Anonymous 2013. R: A language and environment for statistical computing. (version 3.0.2.). R Foundation for Statistical Computing, Vienna, Austria. http://www.R-project.org

Bobori D.C., Moutopoulos D.K., Bekri M., Salvarina I., Muñoz A.I.P. 2010. Length-weight relationships of freshwater fish species caught in three Greek lakes. Journal of Biological Research 14: 219-224.

D'Alessandro W., Katsanou K., Lambrakis N., Bellomo S., Brusca L., Liotta M. 2013. Chemical and isotopic charac- 
terisation of bulk deposition in the Louros Basin (Epirus, Greece). Atmospheric Research 132-133: 399-410. DOI: 10.1016/j.atmosres.2013.07.007

Froese R. 2006. Cube law, condition factor and weight-length relationships: history, meta-analysis and recommendations. Journal of Applied Ichthyology 22 (4): 241-253. DOI: 10.1111/j.1439-0426.2006.00805.x

Froese R., Tsikliras A.C., Stergiou K.I. 2011. Editorial note on weight-length relations of fishes. Acta Ichthyologica et Piscatoria 41 (4): 261-263. DOI: 10.3750/AIP2011.41.4.01

Kleanthidis P.K., Sinis A.I., Stergiou K.I. 1999. Length-weight relationships of freshwater fishes in Greece. Naga, the ICLARM Quarterly 22 (4): 37-40.

Kottelat M., Freyhof J. 2007. Handbook of European Freshwater Fishes. Kottelat and Freyhof, Cornol, Switzerland, Berlin, Germany.

Le Cren E.D. 1951. The length-weight relationship and seasonal cycle in gonad weight and condition in the perch (Perca fluviatilis). Journal of Animal Ecology 20 (2): 201-219. DOI: $10.2307 / 1540$

Liasko R., Anastasiadou Ch., Ntakis A., Gkenas C., Leonardos I.D. 2012. Morphological differentiation among native trout populations in north-western Greece. Journal of Biological Research 17: 33-43.

Moutopoulos D.K., Ramfos A., Mouka A., Katselis G. 2013. Length-weight relations of 34 fish species caught by smallscale fishery in Korinthiakos Gulf (central Greece). Acta Ichthyologica et Piscatoria 43 (1): 57-64. DOI: 10.3750/AIP2013.43.1.08

Oikonomou A., Leprieur F., Leonardos I.D. 2014. Biogeography of freshwater fishes of the Balkan Peninsula. Hydrobiologia. DOI: 10.1007/s10750-014-1930-5.
Petrakis G., Stergiou K.I. 1995. Weight-length relationships for 33 fish species in Greek waters. Fisheries Research 21 (3-4): 465-469. DOI: 10.1016/0165-7836(94)00294-7

Petriki O., Gousia E., Bobori D.C. 2011. Weight-length relationships of 36 fish species from the River Strymon system (northern Greece). Journal of Applied Ichthyology 27 (3): 939-941. DOI: 10.1111/j.1439-0426.2010.01578.x

Sapounidis A., Koutrakis E.T., Leonardos I.D. 2011. Weight-length relationships of 13 species from a flow regulated Balkan river. Journal of Applied Ichthyology 27 (6): 1406-1407. DOI: 10.1111/j.1439-0426.2011.01788.x

Tesch F.W. 1971. Age and growth. Pp. 99-130. In: Ricker W.E. (ed.) Methods for assessment of fish production in fresh waters. Blackwell Scientific Publications, Oxford, UK.

Tsoumani M., Apostolidis A.P., Leonardos I.D. 2013. Length-weight relationships of Rutilus species from fifteen Greek lakes. Journal of Applied Ichthyology 29 (1): 297-298. DOI: 10.1111/jai.12014

Tsoumani M., Liasko R., Moutsaki P., Kagalou I., Leonardos I. 2006. Length-weight relationships of an invasive cyprinid fish (Carassius gibelio) from 12 Greek lakes in relation to their trophic states. Journal of Applied Ichthyology 22 (4): 281-284. DOI: 10.1111/j.14390426.2006.00768.x

Received: 10 January 2014

Accepted: 2 April 2014

Published electronically: 30 June 2014 